\title{
PENGARUH DEBT TO EQUITY RATIO, DAN EARNING PER SHARE TERHADAP HARGA SAHAM PADA PERUSAHAAN MANUFAKTUR YANG GO PUBLIC DI BURSA EFEK INDONESIA.
}

\author{
Pebrianti Ginting ${ }^{1}$, Kornel Munthe ${ }^{2}$ \\ Universitas Katolik Santo Thomas Medan Jl. Setia Budi No. 479F, 20132, Indonesia \\ e-mail: ekounikast.thomas@yahoo.com ${ }^{1}$, kornel_munthe@yahoo.com²
}

\begin{abstract}
The aim of this research is to analyze the influence of debt to equity ratio and earning per share the stock prices of manufacturing companies listed at the Indonesian Stock Exchange. The method of analysis used was linier multiple regression model. This research used secondary data, annual report of the manufacturing corporations during 2012-2014 with 120 unit of corporation as population and 30 unit taken sample by using purposive sampling method. The result of the research indicate that: debt to equity ratio have negative and not significant influence on the stock prices of the corporation, while earning per share have positive and signifikan influence on the stock prices of the corporation. Simultaneously debt to equity ratio and earning per share have signifikan influence on the stock prices of the corporation.
\end{abstract}

KeyWords: debt to equity ratio, earning per share, stock prices

\section{PENDAHULUAN}

Pasar modal merupakan sarana yang paling efektif bagi para investor dalam menanamkan modalnya untuk memperoleh keuntungan. Oleh karena itu pasar modal menjadi sarana bagi pihak yang mempunyai kelebihan dana untuk melakukkan investasi dalam jangka menengah ataupun jangka panjang Husnan (2001) mengatakan bahwa "Pasar modal adalah kegiatan instrumen keuangan atau sekuritas jangka panjang yang dapat diperjual belikan, baik dalam bentuk hutang atau modal sendiri, yang di terbitkan oleh pemerintah atau perusahaan swasta". Permadhy (2005) mengemukakan bahwa pasar modal bermanfaat untuk perluasan usaha, memperbaiki struktur modal, mendorong laju pembangunan, mendorong investasi dan memperoleh dividen bagi yang memiliki saham dan bunga tetap mengambang bagi pemegang obligasi.

Investasi merupakan komitmen atas sejumlah dana atau sumber daya lain yang dilakukan pada saat ini dengan tujuan untuk mendapatkan keuntungan untuk masa yang akan datang (Tandelin,2001). Salah satu aspek yang dinilai oleh investor yaitu kinerja keuangan. Pada prinsipnya semakin baik prestasi perusahaan dapat meningkatkan permintaan saham perusahaan, sehingga akan meningkatkan harga saham perusahaan.

Saham merupakan tanda penyertaan ataupun kepemilikan seseorang atau badan dalam suatu perusahaan (Fred dan Copeland, 1999). Selembar saham yaitu selembar kertas yang menerangkan bahwa pemilik kertas tersebut adalah pemiliknya dari suatu perusahaan yang menerbitkan kertas (saham), ketika memutuskan untuk pendanaan perusahaan. Saham merupakan instrumen investasi yang banyak dipilh para investor karena saham mampu memberikan tingkat keuntungan yang menarik. Dengan membeli saham suatu perusahaan berarti investor menginvestasikan modal atau dana yang nantinya akan digunakan oleh pihak manajemen untuk membiayai kegiatan operasional perusahaan. Menilai harga saham merupakan hal yang mendasar dan harus diketahui oleh investor. Mengingat tanpa penilaian dan analisis yang baik dan rasional, para investor kemungkinan akan mengalami kerugian apabila berinvestasi pada saham yang salah. Keputusan untuk membeli saham terjadi apabila nilai perkiraan suatu saham dimasa mendatang akan berada diatas harga pasar, sebaliknya keputusan untuk menjual saham terjadi apabila nilai perkiraan suatu saham akan berada dibawah harga pasar. 
Nilai perusahaan merupakan persepsi investor terhadap tingkat keberhasilan perusahaan yang sering dikaitkan dengan harga saham. Harga saham yang tinggi membuat nilai perusahaan juga tinggi. Nilai perusahaan yang tinggi akan membuat pasar percaya tidak hanya pada kinerja perusahaan saat ini namun pada prospek perusahaan di masa yang akan datang. Semakin tinggi harga saham, maka akan semakin tinggi pula kemakmuran pemegang saham. Memaksimalkan kemakmuran pemegang saham juga berarti manajemen harus memaksimalkan nilai sekarang dari return yang di harapkan di masa yang akan datang. Jika perusahaan mencapai prestasi yang baik, maka saham perusahaan tersebut akan banyak diminati oleh para investor. Prestasi yang baik tersebut yang akan di publikasikan oleh perusahaan. Faktor utama yang menyebabkan harga saham berubah adalah karena dipengaruhi oleh dua faktor yaitu faktor internal dan faktor eksternal, faktor internal disebut juga faktor fundamental adalah faktor yang berasal dari dalam perusahaan dan dapat juga dikendalikan oleh manajemen perusahaan, sedangkan faktor eksternal yaitu merupakan faktor non fundamental biasanya dapat disebabkan oleh kondisi ekonomi seperti suku bunga dan kebijakan pemerintah (Natarsyah, 2000).

Pada dasarnya investor mengukur kinerja perusahaan berdasakan kemampuan beberapa perusahaan dalam mengelola sumber dana yang dimiliki untuk menghasilkan keuntungan. Kemampuan perusahaan untuk menghasilkan laba dalam kegiatan operasinya merupakan fokus utama dalam penilaian kinerja perusahaan, karena laba merupakan indikator kemampuan perusahaan dalam memenuhi kewajibannya kepada para penyandang dana. Jika suatu perusahaan memiliki kinerja keuangan yang baik maka investor akan menanamkan modalnya, karena bisa dipastikan akan memperoleh keuntungan dari penanaman modal tersebut. Penilaian kinerja keuangan perusahaan dalam menghasilkan laba dari investasi yang akan dilakukan tersebut sebagai rasio profitabilitas. Analisis laporan keuangan yang meliputi perhitungan dan interprestasi rasio diperlukan untuk dapat memahami informasi tentang laporan keuangan. Rasio yang dimaksud adalah suatu angka yang menunjukkan hubungan antara suatu unsur dengan unsur lainnya dalam laporan keuangan. Rasio keuangan digunakan untuk menentukan untuk pembelian atau penjualan saham suatu perusahaan, pemberian pinjaman serta untuk memprediksi kekuatan keuangan perusahaan dimasa yang akan datang.

Analisis rasio keuangan merupakan alternatif untuk menguji apakah informasi keuangan bermanfaat untuk melakukan klasifikasi atau prediksi terhadap harga saham. Analisis rasio keuangan didasarkan pada data keuangan historis yang tujuan utamanya memberikan indikasi kinerja perusahaan yang akan datang. Dalam melakukan investasi dipasar modal apakah investor akan mempertimbangkan faktor fundamental beberapa perusahaan, seperti kinerja perusahaan yang diproyeksikan dengan rasio keuangan untuk memperkirakan harga saham yang akan diterima dimasa yang akan datang. Rasio keuangan yang digunakan yaitu debt to equity ratio dan earning per share.

Debt to equity ratio adalah perbandingan antara dana pinjaman atau hutang dibandingkan dengan modal dalam upaya pengembangan perusahaan. Rasio ini menunjukkan perbandingan antara dana pinjaman atau utang dan ekuitas dalam upaya pengembangan perusahaan. Semakin rendah DER menandakan modal yang digunakan dalam operasional perusahaan semakin kecil, sehingga risiko yang ditanggung investor juga akan semakin kecil dan kemungkinan akan meningkatkan harga saham. Semakin besar DER menunjukkan bahwa struktur modal lebih memanfaatkan hutang dibandingkan dengan modal sendiri.

Hasil penelitian Setiawan (2011) menemukan bahwa secara simultan return on assets, debt to equity ratio dan price to book value berpengaruh signifikan terhadap harga saham sedangkan secara parsial return on assets, dan price to book value berpengaruh signifikan terhadap harga saham, sedangkan debt to equity ratio tidak berpengaruh signifikan terhadap harga saham. Patriawan (2009) menemukan bahwa earning per share berpengaruh positif dan signifikan terhadap harga saham, return on equity berpengaruh negatif dan tidak signifikan 
terhadap perubahaan harga saham. Sedangkan debt to equity ratio berpengaruh negatif dan tidak signifikan terhadap perubahaan harga saham.

Earning per share adalah Rasio yang banyak diperhatikan oleh calon investor, sebab informasi EPS merupakan informasi yang dianggap paling mendasar dan dapat menggambarkan prospek earning perusahaan dimasa depan. Syamsuddin (2007) mengemukakan bahwa manajemen perusahaan, pemegang saham biasa dan calon pemegang saham tertarik terhadap EPS yang besar karena hal tersebut menggambarkan jumlah rupiah yang diperoleh setiap lembar saham biasa. Hasi penelitian Pratama dan Erawati (2014); Itabillah (2013) menemukan bahwa EPS berpengaruh signifikan dan positif terhadap harga saham. Mariana (2008) menemukan scara simultan variabel EPS, PER, dan ROE berpengaruh signifikan terhadap harga saham, sedangkan secara parsial hanya variabel EPS yang memiliki pengaruh dan signifikan terhadap harga saham. Sedangkan Miranda (2011) menemukan bahwa secara parsial dan simultan variable EPS, DPS dan FL berpengaruh signifikan terhadap harga saham. Dari beberapa hasil penelitian yang dikemukakan diatas menunjukkan bahwa pengaruh kinerja keuangan terhadap harga saham yang masih variatif atau berbeda-beda. Hal tersebut merupakan salah satu yang mendorong peneliti untuk melakukan penelitian tentang pengaruh kinerja keuangan terhadap harga saham.

\section{TINJAUAN PUSTAKA}

\section{A. Saham}

Saham adalah surat bukti atau kepemilikan bagian modal suatu perusahaan. Saham adalah salah satu sumber dana yang diperoleh perusahaan yang berasal dari pemilik modal dengan konsekuensi perusahaan harus membayar dividen. Menurut Anoraga dan Pakarti (2008) bahwa: "Saham merupakan tanda penyertaan modal pada suatu perseroan terbatas". Dalam pasar modal yang efesien semua sekuritas diperjual-belikan pada harga pasar. Harga pasar saham adalah harga yang ditentukan oleh investor melalui pertemuan permintaan dan penawaran. Pertemuan ini dapat terjadi karena para investor sepakat terhadap harga suatu saham. Harga saham mengalami perubahan naik turun dari satu waktu ke waktu lain. Perubahan tersebut tergantung pada kekuatan permintaan dan penawaran, apabila suatu saham mengalami kelebihan permintaan, maka harga saham cenderung naik. Sebaliknya jika terjadi kelebihan penawaran, maka harga saham cenderung turun. Saham dapat didefenisikan sebagai tanda penyertaan modal seseorang atau pihak (badan usaha) dalam suatu perusahaan atau perseroan terbatas.

Menurut Anoraga dan Pakarti (2008) berdasarkan fungsinya, nilai suatu saham dibagi atas tiga jenis, yaitu sebagai berikut:

a. Par Value (Nilai Nominal)/Stated Value /Face Value, Nilai nominal ini tidak digunakan untuk mengukur sesuatu. Jumlah saham yang dikeluarkan perseroan dikali dengan nilai nominalnya merupakan modal disetor penuh bagi suatu perseroan dan dalam pencatatan akuntansi nilai nominal dicatat sebagai modal ekuitas perseroan di dalam neraca. Untuk satu jenis saham yang sama harus mempunyai satu jenis nilai nominal.

b. Base Price (Harga Dasar), Harga dasar suatu saham sangat erat kaitannya dengan harga pasar suatu saham. Harga perdana untuk menentukan nilai dasar, dipergunakan dalam perhitungan indeks harga saham. Harga dasar akan berubah sesuai dengan aksi emiten. Untuk saham baru, harga dasar merupakan harga perdananya.

c. Market Price (Harga Pasar), Market Price merupakan harga pada pasar riil dan merupakan harga yang paling mudah ditentukan karena merupakan harga dari suatu saham pada pasar yang sedang berlangsung atau jika pasar sudah tutup, maka harga pasar adalah harga penutupannya (closing price). Harga ini terjadi setelah saham tersebut dicatatkan di bursa, baik bursa utama maupun OTC (Over The Counter Market). Transaksi di sini sudah tidak lagi melibatkan emiten dan penjamin emisi. Harga pasar ini merupakan harga jual dari investor yang satu dengan investor yang lain dan disebut sebagai harga di pasar 
sekunder. Harga pasar inilah yang menyatakan naik-turunnya suatu saham dan setiap hari diumumkan di surat-surat kabar atau di media-media lainnya.

Menurut Anoraga dan Pakarti (2008) bahwa dengan memiliki saham suatu perusahaan, maka manfaat yang diperoleh di antaranya berikut ini: (a) Dividen, bagian dari keuntungan perusahaan yang dibagikan kepada pemilik saham, (b) Capital gain, adalah keuntungan yang diperoleh dari selisih harga jual dengan harga belinya, dan (c) Manfaat nonfinancial yaitu timbulnya kebangggaan dan kekuasaan memperoleh hak suara dalam menentukan jalannya perusahaan.

Menurut Jogiyanto (2010) bahwa harga saham adalah harga yang terjadi dipasar bursa pada saat tertentu yang ditentukan oleh pelaku pasar dan ditentukan oleh permintaan dan penawaran saham yang bersangkutan di pasar modal. Faktor-faktor yang mempengaruhi harga saham adalah:

1. Laba per lembar saham. Seorang investor yang melakukan investasi pada perusahaan akan menerima laba atas saham yang dimilikinya. Semakin tinggi laba per lembar saham nya (EPS) yang diberikan perusahaan, maka akan memberikan pengembalian yang cukup baik. Ini akan mendorong investor untuk melakukan investasi lebih besar lagi sehingga harga saham perusahaan meningkat pesat.

2. Tingkat Bunga, tingkat bunga mempengaruhi harga saham dengan cara: (a) Mempengaruhi persaingan di pasar modal antara saham dengan obligasi, apabila suku bunga naik maka investor akan menjual sahamnya untuk ditukarkan dengan obligasi. Hal ini akan menurunkan harga saham, sebaliknya juga akan terjadi apabila tingkat bunga mengalami penurunan. (b) Mempengaruhi laba perusahaan, hal ini terjadi karena bunga adalah biaya. Semakin tinggi suku bunga maka akan semakin rendah laba perusahaan. Suku bunga juga mempengaruhi kegiatan ekonomi yang juga akan mempengaruhi laba perusahaan.

3. Jumlah kas dan dividen yang diberikan.

4. Kebijakan pembagian dividen dapat dibagi menjadi dua, yaitu sebagian dibagikan dalam bentuk dividen dan sebagian lagi disisihkan sebagai laba ditahan. Sebagai salah satu faktor yang mempengaruhi harga saham, maka peningkatan pembagian dividen merupakan salah satu cara untuk meningkatkan kepercayaan dari pemegang saham itu sendiri. Karena jumlah kas dividen yang besar adalah yang diinginkan oleh investor sehingga harga saham naik.

5. Jumlah laba yang didapat perusahaan. Pada umumnya, investor melakukan investasi pada perusahaan yang mempunyai profit yang cukup baik karena menunjukkan prospek yang cerah dan membuat investor tertarik untuk berinvestasi. Yang mana nantinya akan mempengaruhi harga saham perusahaan tersebut.

6. Tingkat risiko dan pengembalian. Apabila risiko dan proyeksi laba yang diharapkan perusahaan meningkat, maka akan mempengaruhi harga saham perusahaan. Biasanya semakin tinggi risikonya maka akan semakin tinggi pula tingkat pengembalian saham yang diterima. Sedangkan menurut Arifin (2002) ada beberapa faktor yang mempengaruhi harga saham. Faktor-faktor tersebut antara lain: (a) Kondisi Fundamental Perusahaan, (b) Hukum Permintaan dan Penawaran, (c) Tingkat Suku Bunga, (d) Valuta Asing, (e) Dana Asing di Bursa, (f) Indeks Harga Saham Gabungan, (g) Isu Yang Terkait

B. Analisis yang digunakan dalam penilaian harga saham adalah:

a. Analisis Teknikal. Menurut Anoraga dan Pakarti (2006) pendekatan teknikal sering dipakai oleh investor, dan biasanya data yang digunakan dalam pendekatan ini berupa grafik. Meskipun biasanya pendekatan ini digunakan untuk menganalisis dalam jangka pendek, dan jangka menengah, tetapi sering juga digunakan untuk jangka panjang yang didukung dengan data-data lain. 
Analisis teknikal merupakan upaya untuk memperkirakan harga saham dengan mengamati perubahan harganya diperiode yang lalu dan upaya untk menentukan kapan investor akan membeli, menjual atau mempertahankan sahamnya dengan menggunakan indikato-indikator teknis atau menggunakan analisis grafik. Indikator yang sering digunakan adalah Moving avege (tren yang mengikuti pasar), volume perdagangan dan short-interest ratio. Sedangkan analisis grafik diharapkan dapat mengidentifikasi berbagai pola seperti key reserval, head and shoulders, dan sabagainya. Dengan analisis ini dimungkinkan untuk mengetahui perkembangan suatu atau beberapa kejadian serta hubungan/pengaruhnya terhadap kejadian lainnya. Analisis ini menggunakan data pasar dari saham, seperti harga dan volume transaksi penjualan saham untuk menentukan nilai sahamnya.

b. Analisis Fundamental. Pendekatan atau analisisn fundamental merupakan metode penilaian harga saham yang menggunakan financial analysis dan economic analysis untuk memperkirakan pergerakan harga saham. Analisis fundamental merupakan faktor yang erat kaitannya dengan kondisi perusahaan yaitu kondisi manajemen organisasi sumber daya manusia dan kondisi keuangan perusahaan yang tercermin dalam kinerja keuangan perusahaan. Menurut Husnan (2001), analisis fundamental mencoba memperkirakan harga saham dimana yang akan datang dan menetapkan hubungan variabel-variabel tersebut sehingga diperoleh taksiran harga saham. Menurut Jogiyanto (2010), analisis fundamental merupakan analisis yang menggunakan data-data finansial yaitu data-data yang berasal dari laporan keuangan perusahaan, seperti laba,dividen yang dibagikan, dan sebagainya. Tryfino (2009) mengemukakan bahwa" pendekatan fundamental metode analisis berdasarkan kinerja keuangan dalam suatu perusahaan. Pendekatan fundamental juga merupakan pendekatan analisis harga saham yang menitikberatkan pada kinerja perusahaan yang mengeluarkan saham.

\section{Debt to Equity Ratio}

Salah satu rasio yang paling banyak digunakan adalah rasio utang terhadap ekuitas atau debt to equity ratio. Besarnya hutang yang terdapat dalam struktur modal perusahaan sangat penting untuk memahami perimbangan antar risiko dan laba yang didapat. Hutang membawa risiko karena setiap hutang pada uumnya akan menimbulkan keterikatan yang tetap bagi perusahaan untuk membayar beban bunga serta cicilan kewajiban pokoknya. Debt to equity ratio mencerminkan kemampuan perusahaan dalam memenuhi seluruh kewajibannya, yang ditunjukkan oleh berapa bagian modal sendiri yang digunakan untuk membayar hutang. Menurut Riyanto (2000) bahwa salah satu rasio yang termasuk dalam rasio solvabilitas atau leverage adalah debt to equity ratio. Husnan (2001) mengemukakan DER menunjukkan perbandingan antara hutang yang diberikan oleh para kreditur dengan jumlah modal sendiri yang diberikan oleh pemilik perusahaan. Rasio ini digunakan untuk mengetahui berapa bagian dari setiap modal sendiri yang dijadikan jaminan untuk keseluruhan hutang perusahaan atau untuk menilai banyaknya hutang yang dipergunakan oleh perusahaan. Kreditor jangka panjang pada umumnya lebih menyukai DER yang kecil. Semakin kecil rasio DER, maka akan semakin kecil jumlah modal sendiri yang dikeluarkan oleh perusahaan untuk membiayai hutang .

Dalam memenuhi kebutuhan dana untuk investasi, perusahaan akan memadukan sumber dana permanen yang digunakan perusahaan dengan cara yang dapat memaksimumkan harga saham perusahaan. Ukuran dari bauran pendanaan yang digunakan perusahaan adalah debt to equity ratio. DER akan mempengaruhi harga saham karena rasio ini digunakan untuk mengukur kemampuan perusahaan dalam menutupi sebagian atau seluruh hutanh-hutangnya baik jangka panjang maupun jangka pendek yangg berasal dari modal sendiri. DER adalah rasio yang memberikan gambaran mengenai struktur modal yang dimiliki perusahaan atau keseimbangan proporsi antara aktiva yang didanai oleh kreditor dan yang didanai oleh pemilik perusahaan dan sehingga dapat dilihat tingkat risiko tak 
tertagihnya suatu utang (Prastowo dan Juliaty, 2005). Debt to equity ratio menggambarkan perbandingan antara total utang denag total ekuitas perusahaah yang digunakan sebagai sumber pendanaan usaha. Dimana perusahaan memanfaatkan hutang jangka panjang sebagai pendanaan usahanya, sehingga mengakibatkan semakin besar risiko yang harus ditanggung investor.

Harga saham perusahaan dapat dimaksimumkan, jika perusahaan dapat meminimum kan biaya penggunaan berbagai macam sumber dana. Oleh karen itu, perusahaa perlu mengkombinasikan antara modal sendiri dengan sumber dana yang dapat meminimalkan biaya modal perusahaan dalam proporsi yang paling tepat, sehingga harga saham perusaan dapat meningkat. Oleh karena itu semakin rendah DER akan semakin tinggi kemampuan perusahaan untuk membayar seluruh kewajibannya. Semakin besar proporsi hutang yang digunakan untuk struktur modal suatu perusahaan, maka akan semakin besar pula jumlah kewajibannya (Ang, 1997).

\section{Earning Per Share}

Earning per share adalah termasuk salah satu rasio yang pada dasarnya mengukur kemampuan manajemen dalam menciptakan nilai pasar yang melampaui pengeluaran investasi. Rasio ini merupakan pengukuran yang paling lengkap mengenai prestasi perusahaan dan berkaitan langsung dengan tujuan memaksimalkan nilai perusahaan dan kekayaan para pemegang saham. Menurut (Ang, 1997) bahwa earning per share adalah salah satu rasio pasar yang merupakan hasil atau pendapatan yang akan diterima oleh para pemegang saham untuk setiap lembar saham yang dimilikinya atas ke ikutsertaan dalam perusahaan. Munawir dalam Martono (2009) menyebutkan bahwa Earning per share biasanya merupakan indikator laba yang diperhatikan oleh para investor. Earning Per Share adalah salah satu indikator pendapatan sehingga berpengaruh positif dan signifikan terhadap pergerakan harga saham Taufik dalam Martono (2009). Semakin tinggi laba setelah pajak yang dihasilkan perusahaan maka semakin besar Earning per share perusahaan Subiyantoro \& Andreani dalam Martono (2009). Dalam jangka pendek, rencana pembelian kembali saham mungkin dapat menutupi kondisi perusahaan yang sebenarnya namun hal itu akan mengurangi kepercayaan pemodal terhadap perusahaan, meskipun bagi pemodal pendapatannya sendiri dari saham tersebut meningkat. Akibatnya permintaan akan saham tersebut menurun dan harga saham juga mengalami penurunan (Ang, 1997).

\section{E. Pengaruh Debt to Equity Ratio Terhadap Harga Saham}

Salah satu rasio leverage yang diperhatikan oleh investor adalah debt to equity ratio. Menurut Darsono dan Ashari (2005) bahwa debt to equity ratio adalah rasio yang menunjukkan persentase penyediaan dana oleh pemegang saham terhadap pemberi pinjaman. Debt to equity ratio merupakan salah satu ratio leverage yang diperhatikan oleh investor karena DER dapat menunjukkan komposisi pendanaan dalam membiayai aktivitas operasionalnya antara pendanaan sendiri atau memanfaatkan hutang-hutangnya. Dalam konteks teoritis terdapat hubungan yang negatif antara kenaikan harga saham dengan tingkat hutang yang dilakukan. DER yang tinggi menunjukkan tingginya ketergantungan permodalan perusahaan terhadap pihak luar, sehingga beban perusahaan juga semakin berat. Nilai perusahaan akan menurun jika perusahaan menggunakan utang lebih dari modal sendiri (Sudana, 2011). Bagi investor, semakin besar DER akan semakin tidak menguntungkan karena semakin besar risiko yang ditanggung atas kegagalan yang mungkin terjadi di perusahaan. Semakin besar DER, maka semakin rendah harga saham perusahaan karena perusahaan harus membayar utang dan investor semakin tidak tertarik untuk membeli saham perusahaan.

\section{F. Pengaruh Earning Per Share EPS) Terhadap Harga Saham}

Menurut Widoatmodjo (2005) bahwa earning per share merupakan rasio antara pendapatan setelah pajak dengan jumlah saham yang beredar". Menurut Harahap (2007) 
bahwa earningp per share digunakan untuk mengukur keberhasilan manajemen dalam mencapai keuntungan bagi pemilik perusahaan. Rasio rendah berarti manajemen tidak menghasilkan kinerja yang baik dengan memperhatikan pendapatan-pendapatan yang diperoleh. Rasio tinggi berarti perusahaan sudah mapan. Earning per share merupakan laba bersih yang siap dibagikan kepada pemegang saham dengan jumlah lembar saham perusahaan (Tandelin 2010). Earning per share yang tingi maka dividen yang akan diterima investor akan semakin tinggi. Dividen yang diterima investor merupan daya tarik bagi investor/calon investor yang akan menanamkan dananya kedalam perusahaan tersebut. Daya tarik tersebut memberi dampak pada calon investor/investor untuk lebih meningkatkan kepemilkan saham tersebut. Jika earning per share meningkat/tinggi maka permintaan atas saham perusahaan semakin banyak dari calon investor sehingga harga saham perusahaan di pasar modal cenderung meningkat. Dengan meningkatnya harga saham perusahaan, maka return saham yang akan diperoleh investor juga akan semakin tinggi. Jika nilai earning per share naik maka harga saham juga mengalami kenaikan (Darmidji dan Fakhruddin 2006). Husnan (2001) mengemukakan bahwa jika kemampuan perusahaan untuk menghasilkan laba meningkat, maka harga saham akan meningkat dan return saham yang akan diperoleh pemegang saham juga akan semakin tinggi.

\section{METODE PENELITIAN}

\section{A. Ruang Lingkup Penelitian}

Ruang lingkup penelitian ini meliputi Pengaruh Debt to Equity Ratio dan Earning Per Share terhadap pengaruh Harga Saham pada Perusahaan Manufaktur yang Go Publik di Bursa Efek Indonesia periode 2012-2014.

\section{B. Populasi dan Sampel}

Populasi dalam penelitian ini adalah seluruh perusahaan manufaktur yang Go Public yang terdaftar di Bursa Efek Indonesia pada tahun 2012-2014 yaitu sebanyak 120 perusahaan. Dari populasi di atas diperoleh sampel sebanyak 32 perusahaan dengan menggunakan rumus slovin.

\section{Operasionalisasi Variabel}

1. Variabel Terikat dalam penelitian ini adalah harga pasar per 31 Desember tahun 20122014 yang terdapat pada pasar modal.

2. Variabel Bebas (independent variabel)

a. Debt To Equity Ratio adalah perbandingan antara total hutang dengan ekuitas.

b. Earning Per Share adalah adalah perbandingan antara laba bersih setelah pajak dengan jumlah saham yang beredar.

\section{Teknik Pengumpulan Data}

Teknik pengumpulan data yang digunakan dalam penelitian ini adalah dengan metode dokumentasi dengan mendapatkan data laporan tahunan yang di publikasikan dan telah dikeluarkan oleh perusahaan pada periode tahun 2012-2014. Data tersebut diperoleh dari website $\underline{w w w . i d x . c o . i d}$

\section{E. Teknik Analisis Data}

Metode analisis data yang digunakan dalam penelitian ini adalah analisis regresi linier berganda dengan persamaan sebagai berikut:

$\mathrm{Y}=\alpha+\beta_{1} \mathrm{X}_{1}+\beta_{2} \mathrm{X}_{2}+\mathrm{e}$

Dimana

$\mathrm{Y}=$ Harga Saham $\alpha=$ Angka Konstanta, $\beta_{1}, \beta_{2}=$ koefesien Regresi

$\mathrm{X}_{1}=$ Debt to Equity Ratio, $\mathrm{X}_{2}=$ Earning Per Share, $\mathrm{e}=$ Kesalahan residual 
1. Uji Asumsi Klasik

Ada beberapa uji asumsi klasik yang dilakukan terhadap suatu model regresi diantaranya adalah:

a. Uji Normalitas, Uji normalitas bertujuan untuk mengetahui apakah variabel residual memiliki distribusi normal. Untuk menguji normalitas, penelitian ini menggunakan uji Kolmogorov-Smirnov. Kriteria penilaian uji ini adalah : jika signifikan hasil perhitungan data (Sig) $>5 \%$, maka data berdistribusi normal (Sig) < $5 \%$, maka data tidak berdistribusi normal.

b. Uji Multikolinieritas, Multikolinieritas berarti variabel independen yang satu dengan variabel independen yang lain dalam model regresi memiliki hubungan yang kuat. Untuk mendeteksi apakah model regresi kita mengalami multikolinieritas, dapat diperiksa menggunakan VIF. VIF merupakan singkatan dari Variance Inflation Factor. Nilai VIF $>10$ berarti telah terjadi multikolinieritas yang serius di dalam model regresi kita.

c. Uji Auto Korelasi, Uji autokolerasi bertujuan untuk menganalisis apakah dalam model regresi linear terdapat korelasi antara kesalahan pengganggu pada periode $t$ dengan kesalahan sebelumnya. Pengujian autokorelasi menggunakan uji DurbinWatson (DW test), dengan kriteria sebagai berikut: (a) Bila nilai DW lebih kecil dari 2 maka terdapat autokorelasi positif, $\quad$ (b) Bila nilai DW di antara -2 sampai dengan +2 , berarti tidak terdapat autokorelasi, (c) Bila nilai DW lebih besar dari +2 , maka terdapat autokorelasi negatif.

d. Uji Heteroskedastisitas, Heteroskedastisitas berarti terjadi varian yang tidak sama untuk variabel independen yang berbeda. Hal ini dapat dideteksi dengan mengamati sebaran tititk-titik pada scatterplot antara nilai taksiran $Y$ dengan nilai residual (selisih antara variabel dependen akrual dengan nilai prediksinya), versus nilai prediksinya menyebar atau tidak membentuk pola.

\section{Uji Hipotesis}

Alat analisis yang digunakan untuk mengetahui pengaruh variabel debt to equity ratio dan earning per share terhadap variabel harga saham adalah dengan $\mathbf{U j i} \mathbf{t}$ dan $\mathbf{U j i} \mathbf{F}$

\section{HASIL PENELITIAN DAN PEMBAHASAN}

\section{Analisis Statistik Deskriptif}

Hasil analisis statistik deskriptif untuk variabel debt to equity ratio, earning per share dan harga saham pada perusahaan manufaktur yang Go Public di Bursa Efek Indonesia dengan pengamatan 2012- adalah sebagai berikut:

Tabel 1. Descriptive Statistics

\begin{tabular}{|l|r|r|r|r|r|}
\hline & \multicolumn{1}{|c|}{ N } & Minimum & Maximum & \multicolumn{1}{c|}{ Mean } & Std. Deviation \\
\hline DER & 84 & 4,00 & 515,00 & 112,8452 & 116,33039 \\
\hline EPS & 84 & $-146,45$ & 5334,11 & 320,7933 & 779,41875 \\
\hline HGS & 84 & 86,00 & 25000,00 & 3107,8214 & 5043,41033 \\
\hline Valid N(listwise) & 84 & & & & \\
\hline
\end{tabular}

Sumber: Data diolah 2017

Berdasarkan tabel 1 di atas nampak bahwa nilai rata-rata debt to equity ratio perusahaan sampel adalah 112.84 persen dengan standar deviasi

116.33 persen, untuk earning per share rata-rata adalh $\mathrm{Rp} 320.79$ dengan standard deviasi $\mathrm{Rp} 779$, 42, sedangkan rata-rata harga saham adalah sebesar Rp. 3107. 82 dengan standard deviasi 5.043.41.

2. Uji Asumsi Klasik

Hasil uji asumsi klasik adalah sebagai berikut:

a. Hasil Uji Normalitas, berdasarkan hasil pengujian normalitas dengan menggunakan One Sample Kolmogorov Smirnov diperoleh bahwa nilai Asymp.Sig (2-tailed) untuk 
variable debt to equity ratio sebesar 0,085 persen dengan probabilitas 0,200 sedangkan untuk variabel earning per share sebesar Rp. 0,052 dengan probabilitas sebesar 0,200 dan variabel harga saham sebesar Rp. 0,088 dengan probabilitas 0,162, dengan demikian bahwa data variable-variabel dalam penelitian telah berdistribusi normal karena nilai dari Asymp.sig(2-tailed) untuk semua variabel lebih besar dari 0,05.

b. Hasil Uji Multikolinearitas, hasil uji multikolinearitas terhadap variable debt to equity ratio dan earning per share ditunjukkan pada tabel 2 berikut:

Tabel 2. Coefficient

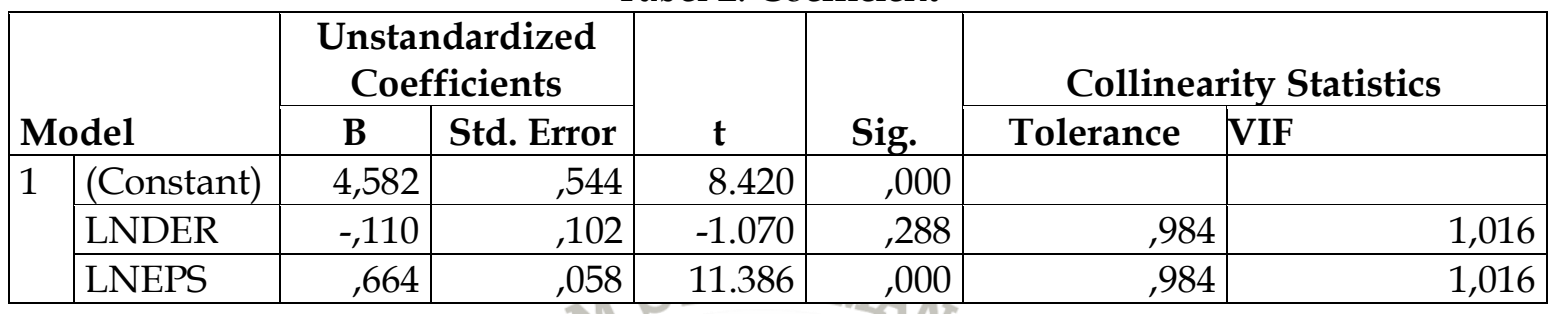

Dari tabel 2 di atas menunjukkan bahwa nilai tolerance dari masing-masing variabel debt to equity ratio dan earning per share adalah $>0,10$ yang berarti tidak terjadi multikolinearitas antara variabel debt to equity ratio dan earning per share.

Hasil Uji Autokorelasi, hasil Uji autokorelasi adalah sebagai berikut:

Tabel 3. Model Summary ${ }^{b}$

\begin{tabular}{|l|l|r|r|r|r|}
\hline Model & R & R Square & $\begin{array}{c}\text { Adjusted R } \\
\text { Square }\end{array}$ & $\begin{array}{c}\text { Std. Error of the } \\
\text { Estimate }\end{array}$ & Durbin-Watson \\
\hline 1 &, $811^{\mathrm{a}}$ &, 657 &, 648 &, 83894 & 1,796 \\
\hline
\end{tabular}

a. Predictors: (Constant), LNEPS, LNDER

b. Dependent Variable: LNHGS

Dari tabel 3 diatas menüjukan hasil uji autokorelasi menghasilkan nilai DurbinWatson sebesar 1,796 berada diäntara -2 sampai dengan +2 maka dapat disimpulkan tidak ada autokorelasi.

c. Hasil Uji Heteroskedastisitas, hasil uji heteroskedastisitas nampak bahwa grafik scatter plot, terlihat titik-titik tersebar secara acak, serta tersebar baik diatas maupun dibawah angka 0 pada sumbuh Y. Maka dapat diambil kesimpulan bahwa tidak terdapat gejala heteroskedastisitas pada model regresi yang digunakan.

\section{Pengujian Hipotesis}

Dari tabel 2 diatas bahwa variabel debt to equity ratio berpengaruh negatif dan tidak signifikan terhadap harga saham pada $a=5$ persen, sedangkan earning per share berpengaruh positif dan signifikan terhadap harga saham pada $\alpha=5$ persen.

Hasil pengujian secara simultan pengaruh antara variabel debt to eouity ratio, dan earning per share terhadap Harga Saham disajikan pada tabel 5 berikut

Tabel 4. ANOVAa

\begin{tabular}{|l|l|r|r|r|r|c|}
\hline \multicolumn{2}{|l|}{ Model } & Sum of Squares & Df & Mean Square & F & Sig. \\
\hline \multirow{3}{*}{1} & Regression & 95,832 & 2 & 47,916 & 68,080 &, $000^{\mathrm{b}}$ \\
\cline { 2 - 7 } & Residual & 49,971 & 71 &, 704 & & \\
\cline { 2 - 7 } & Total & 145,803 & 73 & & & \\
\hline
\end{tabular}

a. Dependent Variable: LNHGS

b. Predictors: (Constant), LNEPS, LNDER

Dari tabel 4 diatas menunjukan bahwa variable debt to equity ratio dan earning per share secara simultan mempunyai pengaruh yang signifikan terhadap harga saham pada $a=5$ 
persen. Dari tabel 3 di atas menunjukkan bahwa nilai $R$ Square sebesar 0,657 yang berarti bahwa besarnya variasi harga saham mampu dijelaskan oleh variasi dari variabel debt to equity ratio dan earning per share sebesar 55,7 persen pada perusahaan manufaktur yang go public di BEI sedangkan sisanya sebesar 34,3 persen oleh variabel lainnya.

\section{PEMBAHASAN}

Pengaruh Debt to Equity Ratio terhadap Harga Saham. Dari tabel 2 di atas terlihat bahwa secara parsial variable debt to equity ratio memiliki pengaruh yang tidak signifikan terhadap harga saham. Pengaruh Debt to Equity Ratio pengaruhnya negatif dan tidak signifikan terhadap harga saham yang artinya bahwa perubahan tingkat hutang pada perusahaan-perusahaan manufaktur yang telah tercatat di pasar modal priode 2012-2014 tidak menyebabkan perubahan pada harga saham. DER adalah rasio yang menggambarkan perbandingan utang dan ekuitas dalam pendanaan perusahaan dan menunjukkan kewajiban, modal sendiri perusahaan tersebut untuk memenuhi seluruh kewajibannya, sedangka nilai DER yang tidak berpengaruh terhadap harga saham disebabkan karena adanya pertimbangan yang berbeda dari beberapa investor dalam memandang DER. Oleh sebagian investor DER dipandang besarnya tanggung jawab perusahaan terhadap pihak ketiga yaitu kreditor yang memberi pinjaman kepada perusahaan, namun demikian nampaknya beberapa investor memandang bahwa perusahaan yang tumbuh pasti memerlukan hutang sebagai dana tambahan untuk memenuhi pendanaan perusaaan pada perusahaan yang tumbuh. Dalam hal ini perusaahaan yang tumbuh akan memerlukan banyak dana operasional yang tidak mungkin dapat dipenuhi hanya dari modal sendiri yang dimiliki perusahaan. Perbedaan pandangan tersebut menyebabkan tidak signifikan DER terhadap haraga saham. Besarnya hutang yang dipakai perusahaan untuk memadai perusahaan dan nilai hutang yang ditanggung oleh perusahaan akan menyebabkan tingginya risiko yang akan ditanggung investor. Oleh karena itu investor lebih menyukai DER yang rendah karena semakin kecil DER maka risiko yang ditanggung investor akan kecil dan jumlah aktiva akan semakin besar. DER mencerminkan kemampuan perusahaan dalam memenuhi kebutuhan perusahaan dalam memenuhi seluruh kewajiban yang mencerminkan beberapa bagian dari modal sendiri yang digunakan untuk membayar hutang. Selain itu jika DER tinggi maka harga saham akan rendah karena jika perusahaan memperoleh laba, perusahaan cenderung mengguna kan laba tersebut untuk membayar hutang dibanding dengan membagi dividen. Sehingga pada penelitian ini menunjukkan bahwa variabel DER tidak digunakan oleh para investor sebagai pertimbangan dalam berinvestasi pada suatu perusahaan. Hal penelitian mendukung hasil penelitian dari Setiawan (2011) dan Partiawan (2009).

Pengaruh Earning Per Share terhadap Harga Saham. Berdasarkan tabel 4 diatas diketahui bahwa secara parsial earning per share berpengaruh positif dan signifikan terhadap harga saham pada perusahaan manufaktur yang Go Public di Bursa Efek Indonesia tahun 2012-2014, yang berarti terdapat hubungan searah antara EPS dengan harga saham. Dalam hal ini semakin tinggi nilai EPS maka harga saham juga akan mengalami peningkatan, dan sebaliknya jika nilai EPS mengalami penurunan maka harga saham juga mengalami penurunan. Adanya hubungan signifikan antara variabel earning per share terhadap harga saham mengandung arti bahwa semakin besar earning per share semakin baik kinerja keuangan perusahaan yang diukur dengan harga saham. Semakin tinggi earning per share maka harga saham mengalami peningkatan sehingga tingkat keuntungan bagi pemegang saham semakin tinggi pula bagi investor sehingga dalam hal ini EPS akan mempengaruhi kepercayaan investor pada perusahaan dan apabila earning per share menurun menandakan investor tidak mau lagi menanamkan sahamnya pada perusahaan tersebut.

Peningkatan EPS menandakan bahwa perusahaan telah berhasil meningkatkan kesejahteraan pemegang saham sehingga memotivasi para pemegang saham untuk jumlah modal yang akan diinvestasikan di perusahaan tersebut yang pada akhirnya akan menaikkan 
harga saham perusahaan tersebut. Hal ini sesuai dengan teori yang dikemukan oleh Husnan (2001) yang mengatakan bahwa jika kemampuan perusahaan untuk menghasilkan laba meningkat, maka harga saham akan meningkat dan return saham yang akan diperoleh pemegang saham juga akan semakin tinggi. Hasil penelitian ini mendukung hasil penelitian dari Miranda (2011); Patriawan (2011) dan Mariana (2008), Itabillah (2013).

\section{KESIMPULAN}

Berdasarkan hasil penelitian dan pembahasan, maka dapat disimpulkan bahwa Debt to equity ratio berpengaruh negatif dan tidak signifikan terhadap Harga Saham sedangkan Earning per share berpengaruh positif dan signifikan terhadap Harga saham. Secara bersamasama Debt to equity ratio dan earning per share berpengaruh signifikan terhadap Harga Saham

\section{DAFTAR PUSTAKA}

Anoraga, P. dan Pakarti.P. 2008. Pengantar Pasar Modal. Edisi Revisi. Jakarta: Rineka Cipta. Ang, Robbert. 1997. Buku Pintar Pasar Modal Indonesia, Edisi 1, Mediasoft Indonesia.

Arifin, Ali. 2002. Membaca Saham . Yogyakarta : Penerbit Andy.

Darmadji dan Fakhruddin, 2006. Pasar Modal Di Indonesia Jilid 3. Jakarta: Salemba Empat.

Darsono dan Ashari, 2005, "Pedoman Praktis Memahami Laporan Keuangan", Yogyakarta: Andi

Fred, Weston, J dan Thomas E, Copeland. 1999. Manajemen Keuangan Edisi 8. Jakrta: Bina Rupa. Aksara.

Harahap. 2007. “Intisari Manajemen Keuangan”, PT Grasindo : Jakarta

Husnan, Suad, 2001. Dasar-dasar Teori Portofolio dan Analisis Investasi. Yogyakarta : UPP AMP YKPN.

Itabillah, Amaliah. 2013. Pengaruh CR, QR, NPM, ROA, EPS, DER dan PBV Terhadap Harga Saham Perusahaan Property dan Reak Estate yang Terdaftar di BEI. (online), tersedia: https://www.google.co.id/url?q=http://jurnal.umrah.ac.id/wpconstant/uploads/ 2013/08/E.AMALTAHTABILLAH,

Jogiyanto. 2010. Teori Portofolio dân Analisis Investasi. Edisi HI. Yogyakarta: BPFE-UGM.

Mariana Uli, Dina. 2008. Analisis Pengaruh Eraning Pen Share (EPS), Price Earning Ratio (PER), dan Return On Equity (ROE) terhadap Harga Saham Perusahaan Makanan dan Minuman Terbuka di BEI Fakultas Ekonomi Universitas Sumatera Utara.

Martono dan D. Agus Harjito. 2007. Manajemen Keuangan. Yogyakarta: Ekonisia.

Miranda, Andini. 2011. Pengaruh Earning Per Share, Dividend Per Share, Dan Financial Leverage Terhadap Harga Saham Pada Perusahaan Food \& Beverage Yang Terdaftar Di Bursa Efek Indonesia. Jurnal ekonomi.

Natarsyha, (2000). Pengaruh ROA, DER, Price To Book Valeu dan Rasio Sistematis Terhadap Harga Saham. Jurnal Analisis Bisnis \& Ekonomi. 2 (1):43-68

Paramitha Idi Putri (2009) " Pengaruh EPS, DER, Kebijakan Dividen, dan Resiko Sistematis terhadap Harga Saham perusahaan yang terdaftar di BEI.

Patriawan, Dwiatma, 2009. Analisis Pengaruh Earning Per Share (EPS), Return on Equity (ROE) dan Debt to Equity Ratio (DER) Terhadap Harga Saham Pada Perusahaan Wholesule and Retail Trade yang Terdaftar di Bursa Efek Indonesia (BEI) Tahun 2006-2008. Universitas Dipenogoro. Semarang.

Permadhy, Yul Tito. 2005. Pengambilan Keputusan Berinvestasi di Pasar Modal. http.//jurnal.pdii.lipi.go.id/admin/jurnal/20053843.pdf. Tanggal akses 14 januari 2012.

Prastowo, Dwi dan Rifka Juliaty, 2005. Analisisi Laporan Keuangan, Konsep dan Aplikasi . Edisi 3. Yogyakarta: UPP STIM YKPN.

Riky, Setiawan. 2011. Pengaruh Return On Aset, Debt to Equity Ratio, dan Price To Book Value Terhadap Harga Saham pada Perusahaan Manufaktur di BEI Tahun 2007-2009. Skripsi. Semarang: Fakultas Ekonomi. Universitas Negeri Semarang. 
Riyanto, Bambang. 2001. Dasar-Dasar Pembelanjaan Perusahaan. Edisi Keempat. Yogyakarta: BPFE

Sartono. 2010. "Manajemen Keuangan Teori dan Aplikasi". Edisi Keempat. Yogyakarta: BPFE.

Sudana, I Made. 2011. Manajemen Keuangan Perusahaan Teori dan Praktik. Jakarta: Erlangga. Jurnal.

Syamsuddin, Lukman. 2007. Manajemen Keuangan Perusahaan. Edisi Baru Jakarta: PT.Rajagrafindo Persada

Tandelilin, Eduardus. 2001. Analisis Investasi dan Manajemen Portofolio. EdisiPertama. BPFE, Yogyakarta.

Taufik, 2005. Kajian Capital Market dan Leverage Terhadap Variasi Harga Saham di Bursa Efek Jakarta. Jurnal Vol 1. Palembang: Unsri.

Tryfino. 2009. "Cara Cerdas Berinvestasi Saham ". Edisi 1, Transmedia Pustaka, Jakarta.Winarno, Widioatmodjo, Sawidji. 2004. Cara Sehat Investasi di Pasar Modal. PT. Rineka Cipta, Jakarta.

www.idx.co.id

www.Sahamok.co.id

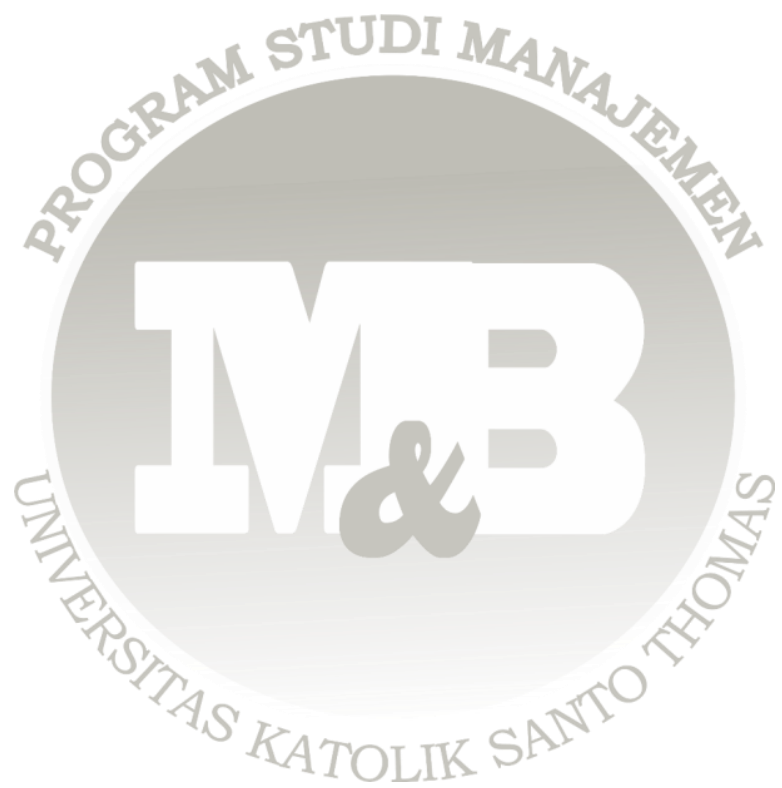

